\author{
P.S. Nosov ${ }^{1}$, I.V. Palamarchuk ${ }^{1}$, S.M. Zinchenko ${ }^{1}$, \\ I.S. Popovych ${ }^{2}$, Ya.A. Nahrybelnyi ${ }^{1}$, H.V. Nosova ${ }^{3}$ \\ ${ }^{1}$ Kherson State Maritime Academy, Ukraine; \\ ${ }^{2}$ Kherson State University, Ukraine; \\ ${ }^{3}$ Kherson Polytechnic College of Odessa National Polytechnic University, Kherson, Ukraine \\ (E-mail:pason@ukr.net)
}

\title{
Development of means for experimental identification of navigator attention in ergatic systems of maritime transport
}

\begin{abstract}
The article discusses the issues of identification of models of analysis of the navigational situation by the navigator during the passage in narrow places and port areas; this is especially relevant in critical situations. As part of the research, an analysis of literary sources was carried out, which made it possible to characterize this direction as actual for the development of special means of an experimental nature. As the main goal, the article presents formal-logical approaches to the development of software and hardware means for determining the areas of attention of the navigator as a subject of an ergatic system. A mechanism was determined for the formation the indexes of the analytical activities of the navigator during assessing the situation, mathematical models, and means for clarifying the position of the navigator on the navigation bridge. A geometric approximation of indexes was proposed, the metric of which can significantly reduce the identification time of critical situations and prevent negative consequences. The carried experiments by using the certified navigation simulator Navi Trainer 5000 confirmed the effectiveness and practical value of the proposed approaches, which will greatly improve the retraining of marine crew.
\end{abstract}

Keywords: experimental tools, identification of attention areas, behavior models, navigator position on the navigation bridge, ergatic systems, critical situations.

\section{Introduction}

Each navigational situation with careful study is unique; however, for a sufficient level of safety, they can be generalized into standard ones, which are described by the rules of the COLREG-72 [1]. However, this approach can reduce the vigilance of the navigator, since the situation at first glance may be misleading. The initial analysis of the situation is performed through the formed experimental relationships and for this reason an error may occur especially if a simplified analysis model is used by the navigator [2].

A particularity of observing a navigation situation $\eta_{i} \in R^{1}$ at the current moment of time $t$ is directly related to a finite set of information signals $I=\{1, \ldots, \varepsilon\}$ coming from: navigation equipment; visual assessment by navigator; sound signals from oncoming vessels [3]. Let us determine that for each of the sources of information signals (SIS), an extremum of attention concentration $r_{i} \in R^{1}$ allows to determine the priority of choice $\varphi_{i}\left(\eta_{i}, r_{i}\right)$. A set of extremums $r=\left(r_{1}, \ldots, r_{\varepsilon}\right) \in R^{\varepsilon}$ in the conditions of discrete identification by the time determines the navigator behavior model during the assessment of the navigation situation.

The aim of the research is to develop software and hardware means and methods for determining areas of concentration of attention with respect to one of the three SIS, $s_{i} \in S_{\tau}$ to identify the navigator behavior model at the time of assessing the situation.

Research Objectives:

1. To determine the mechanism for the formation of orders of analytic activity of the navigator during the assessment of the situation when performing complicated maneuvers.

2. To build mathematical models, software and hardware means to clarify the position of the navigator on the captain's bridge.

3. To develop a formal-hardware interaction of experimental means for identifying the areas of attention of the navigator.

4. To develop visualization of experimental data in the form of a geometric approximation of order, the metric of which allow significantly reduce the identification time of critical situations when the navigator performs complicated maneuvers. 
5. Conduct experiments of the effectiveness of the proposed means of experimental diagnostics of the attention of navigators when navigating a vessel using the navigation simulator Navi Trainer 5000.

\section{Problem statement}

Let us imagine a set of signals regarding the situation as a order $\mathrm{o}_{i}(n)$ formed by experience, which is presented as $n=\left(n_{1}, \ldots, n_{i}\right) \in N=\prod_{\tau=1}^{i} N_{\tau}$. A dynamically changing situation during maneuvering a ship in difficult conditions requires a correct assessment, which is accompanied by a shift of attention relative to the SIS in time. For accurate identification, imagine the order through the signals, then $\eta=\left(\eta_{1}, \ldots, \eta_{6}\right) \in Q^{1, \ldots, 6}$, in this case $0: N \rightarrow Q^{1, \ldots, 6}, n^{\prime} \in N, \forall i \in I, \forall n_{i} \in N_{i}$.

The individuality of the order is based on the priority of appealing to one or another group of information signals: $\rho_{i}\left(\mathrm{o}_{i}\left(n^{\prime}\right), q_{i}\right) \geq \rho_{i}\left(\mathrm{o}_{i}\left(n_{i}, n^{\prime}\right), q_{i}\right)$ where is $n^{\prime} \in N$ the balance of time resources for $\forall i \in I, \forall n_{i} \in N_{i}$ by choosing a sequence of actions from the side of the navigator.

We carry out preliminary modeling of possible strategies for identifying the individual order of assessment of the navigation situation, when $0: Q^{\varepsilon} \rightarrow Q^{\varepsilon}$. Suppose a certain extremum concentration of attention $q \in Q^{\varepsilon}$ is characterized by an order $\eta=\mathrm{o}(q)$, then the assessment of the navigation situation can develop in three ways: $\mathrm{o}_{i}(q)>q_{\tau}$ - excessive order, an oversupply of navigator calls to SIS; $\mathrm{o}_{i}(q)=q_{\tau}$ - the most balanced and effective order; $\mathrm{o}_{i}(q)<q_{\tau}$ - insufficient order.

However, these conclusions can only be preliminary, despite the consistency of the judgments adopted in practice; it is quite difficult to determine whether an individual order belongs to one of the options $\mathrm{o}_{i}(q)$. For this purpose, it is necessary to develop a method for determining appertains $\mu_{i}\left(q_{\tau}\right)$, where the main indicator will be the time spent on the cycle of actions $\Delta \tau$ and the additional indicator will be the utility coefficients of the adopted order. Since the utility of the adopted order $F_{\tau+1}$ is a complex concept, it is convenient to decompose it into components.

The first component $F_{\tau}$ is the available resource within the framework of the technical and cartographical capabilities of the vessel maneuvering. The navigator contingently determines personally the boundaries of the location area in which the navigation situation is considered, which is limited by distance and, as a consequence, by the time $\Delta \tau$. Commonly the time $\Delta \tau$ is limited by maneuvering. At a given speed, it is easy to determine $\Delta \tau$ for the current order. At the same time, the navigator expects a certain result $R_{\tau}$ over a period of time $\Delta \tau$ breaking it into subjectively measured sections. With the passage of each such cycle, the level of stress can both increase and decrease. The polarity of the result within limits [-1;1] indicates the correctness of the adopted strategy in the formation of the order. With the aim to identify the polarity dependent on the stress state of the navigator, a heart rate monitor is used to determine the temperature, pulse and oxygen in the blood as a factor of presence of a stressful situation. In its turn, during the execution of the maneuver, the navigator determines the probability of the expected result, which forms an individual reaction rate coefficient $\lambda_{\tau}$ for both results - positive and negative $R_{\tau}$ for a period of time $\Delta \tau$ in the range $[0 ; 1]$.

One of the significant factors influencing the usefulness of the order is the coefficient of teamwork $T_{\tau}$ [4]. It is also important to take into account the coefficient of deviation from a given course $\varphi_{\tau} c_{\tau}$, which can significantly affect the safety of the overall maneuver. In addition, it is necessary to take into account the value $A_{\tau-v}$, in the form of the time resource obtained from the selection of the effective order, this value is also directly related to the experience of performing such maneuvers. At the time when the maneuver is performed on $2 / 3$, the probability of its successful completion increases and a time interval $A_{\tau}$ appears for choosing the order at time $\tau+1$. At the end of the formal description of the components of utility of the or$\operatorname{der} F_{\tau+1}$, it is necessary to take into account the sum of the time ranges spent on appealing the sources of navigation signals: $\sum_{\gamma=\tau-v}^{\tau-1} \lambda_{A} A_{\gamma}: F_{\tau+1}=F_{\tau}-\left(R_{\tau}+\lambda_{\tau}+T_{\tau}-\varphi_{\tau} c_{\tau}+\left(A_{\tau-v}-A_{\tau}\right)+\sum_{\gamma=\tau-v}^{\tau-1} \lambda_{A} A_{\gamma}\right)$. 


\section{Method of experiment}

Denote by $\alpha, \beta, \delta$ - preferences in the form of a choice of one of three groups of information signals on the set of alternatives $X$ such that $\alpha, \beta, \delta \in \Lambda$, from which it follows that the order of preference has the form: $\alpha \succ \beta \succ \delta$. In this case, it is advisable to consider one of the variations at the current point in time: $\alpha \succ \beta ; \alpha \succ \delta ; \beta \succ \alpha ; \beta \succ \delta ; \delta \succ \alpha ; \delta \succ \beta$ which determine the order of analysis of the navigation situation, for convenience we present the variations as $\theta_{\tau} \Rightarrow \theta_{\tau+1}$.

The principle of the generated order is denoted as $f(\pi) \in \Re, \pi \in Y$, where $Y$ is the set of strategies for the individual formation of the order $\mathrm{o}(q)$.

Then for each variation $\left(\theta_{\tau}, \theta_{\tau+1}\right) \in \Lambda \times \Lambda$ we determine the strength of preference $L_{\theta_{\tau}, \theta_{\tau+1}, f}=\left\{\pi: \pi \in Y,\left(\theta_{\tau}, \theta_{\tau+1}\right) \in f(\pi)\right\}$.

Formed variations as fragments of order determine an individual model for assessing the situation, which includes a dominant approach [5] (1):

$$
\vartheta\left(\theta_{\tau}, \theta_{\tau+1}, f, \pi\right)=\left\{\begin{array}{l}
\mu\left(L_{\theta_{\tau}, \theta_{\tau+1}, f}\right), \text { if } \pi \in L_{\theta_{\tau}, \theta_{\tau+1}, f}, \\
\mu\left(L_{\theta_{\tau}, \theta_{\tau+1}, f}^{*}\right)=1-\mu\left(L_{\theta_{\tau}, \theta_{\tau+1}, f}\right), \text { if } \pi \notin L_{\theta_{\tau}, \theta_{\tau+1}, f} .
\end{array}\right.
$$

In this case, a situation arises when $\mu\left(L_{\theta_{\tau}, \theta_{\tau+1}, f}\right) \geq 0,5$ or $\mu\left(L_{\theta_{\tau}, \theta_{\tau+1}, f}^{*}\right) \geq 0,5$, therefore $\mu\left(W^{*}\right) \geq 0,5$ where $w^{*} \in W_{L_{\theta_{\tau}, \theta_{\tau+1}, f}^{*}, L_{\theta_{\tau}, \theta_{\tau+1}, f}^{*}, \quad \text { that determines the }}^{*}$ $\vartheta\left(\alpha, \beta, f, w^{*}\right) \geq \vartheta(\alpha, \beta, f, \pi) \forall \pi \in Y$.

From the expression it becomes clear that the individually formed relationship of the two elements of order $\theta_{\tau} \Rightarrow \theta_{\tau+1}$ plays a decisive role in its formation. Navigator with more experience has stronger communication criterion $k$ and the lower the level of self-criticism [6]. In practice, it is proved that navigators older than 45 years practically do not deviate from the selected decision-making models and do not change their behavior strategies.

Therefore, the task is to classify decision-making models by the navigator in the conditions of formed chains of links $x$ with the aim to prevent negative consequences.

During the experiment, communication fragments $x \in X$ were revealed with a degree of probability such that $P(A), A \subseteq X$. Then the classification $H$ of the set $X$ on $r$ classes is determined by the functional: $H(X)=\left(h_{1}(x), h_{2}(x), \ldots, h_{r}(x)\right)$, where $h_{i}(x)$ is the membership of $x$ in the $i$-th class, where $r$ is their numerical limit.

Concentration of attention on fragments of the interface of navigation displays, as well as visual observation of the situation, makes it possible to define a point cloud interpreted as a class-forming set $B$. Thus, it becomes possible to form both an order trajectory and a degree of concentration of attention $J$ from a cluster of points with respect to free emissions $u[7,5]: J=-\sum_{i=1}^{r} \int_{X}\left(x-u_{i}\right)^{2} h_{i}(x) d P(x)$.

In connection with the indicated formulations, it becomes necessary to develop a method for determining the direction of view. Considering that it is difficult to technically allocate Eye-tracker devices in conditions of equipping a navigation bridge or a full functional simulator, an approach is proposed based on an analysis of the location of the pupils relative to the navigator's eye section.

This method is proposed to be divided into two stages, the first will allow us to identify the position of the navigator relative to the center of the navigation bridge, and the second will allow us to identify the area of attention concentration by identifying the position of the pupils.

For the technical implementation of the first stage, it is necessary to carry out a formal description of the method that allows us to determine the location of the navigator in expanse based on hardware and software provision.

In order to identify the position of members of the navigation watch crew, a system consisting of beacons and sensors of the server control module is used (Fig. 1). Beacons $M_{i},(i \in(1 . . m))$, are BLE-transmitters 
(Bluetooth Low Energy), made using Arduino technology in conjunction with the AT-09 BLE module and Wi-Fi module ESP8266. All beacons have portable batteries that provide autonomy. $D_{k}$ sensors are connected to all $M_{i}$ beacons in turn and receive packet transmission time from them. Based on this time, the distance $S_{i k}$ between the beacon $M_{i}$ and the sensor $D_{k}$ is determined with some error $p$. To definitely determine the coordinates of the location of an object with a sensor, it is necessary to obtain information from at least three beacons.

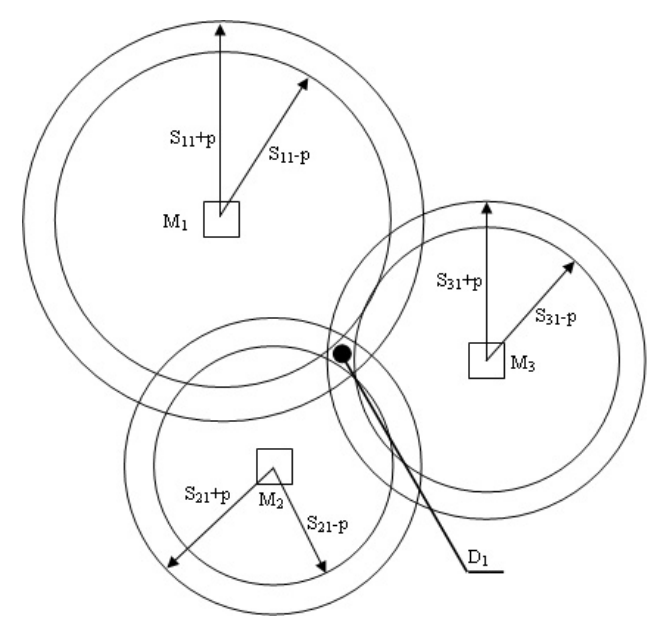

Figure 1. General scheme of the system

We perform mathematical modelling according to the data that are transmitted by three sensors in a Cartesian coordinate system [8]. We will use to find the location of the object by the rangefinder method, applying the formula $D_{i}=\sqrt{\left(x_{i}-x\right)^{2}+\left(y_{i}-y\right)^{2}+\left(z_{i}-z\right)^{2}}$, where $D_{i}$ is the distance between the $i$-th beacon and the object of observation; $x_{i}, y_{i}, z_{i}$ - coordinates of the $i$-th satellite known at the time of measurement; $x, y, z$ - unknown coordinates of the observation object.

To find the location of the object of observation, it is necessary to find the coordinates of the intersection of three spheres, that is, need to know the distance to three beacons. And the coordinates of the object of observation are a solution to a system of three equations $D_{1}, \ldots, D_{2}$ :

In this method, it is assumed that the distances to the beacons are accurate, but since there is a problem of a measurement error by the device (beacon), we will use the pseudo-ranging method to find the location of the object.

Pseudo-range refers to the measured range $D_{\mathrm{ch} i}$ to the $i$-th beacon, which differs from the true range by an unknown, but constant value for the time of determination $D^{\prime}$. Thus, for pseudo-range to the $i$-th beacon, we can write: $D_{\text {ch } i}=D_{i}+D^{\prime}=\sqrt{\left(x_{i}-x\right)^{2}+\left(y_{i}-y\right)^{2}+\left(z_{i}-z\right)^{2}}+D^{\prime}$.

In the pseudo-rangefinder method, the position surface is still a sphere, but the radius of this sphere is changed to an unknown value $D^{\prime}$.

Measurement of pseudo-range up to three beacons leads to a system of equations with four unknowns $\left(x, y, z, D^{\prime}\right)$. To eliminate the arising uncertainty, it is necessary to carry out additional measurements, i.e. measure the pseudo-range to the fourth beacon. The system of four equations obtained in this way has an exact solution, and therefore the coordinates of the object of observation are determined as the intersection point of the four position surfaces:

$$
\left\{\begin{array}{l}
D_{1}+D^{\prime}=\sqrt{\left(x_{1}-x\right)^{2}+\left(y_{1}-y\right)^{2}+\left(z_{1}-z\right)^{2}}, \\
D_{2}+D^{\prime}=\sqrt{\left(x_{2}-x\right)^{2}+\left(y_{2}-y\right)^{2}+\left(z_{2}-z\right)^{2}}, \\
D_{3}+D^{\prime}=\sqrt{\left(x_{3}-x\right)^{2}+\left(y_{3}-y\right)^{2}+\left(z_{3}-z\right)^{2}}, \\
D_{4}+D^{\prime}=\sqrt{\left(x_{4}-x\right)^{2}+\left(y_{4}-y\right)^{2}+\left(z_{4}-z\right)^{2}},
\end{array},\left\{\begin{array}{l}
\left(D_{1}+D^{\prime}\right)^{2}=\left(x_{1}-x\right)^{2}+\left(y_{1}-y\right)^{2}+\left(z_{1}-z\right)^{2}, \\
\left(D_{2}+D^{\prime}\right)^{2}=\left(x_{2}-x\right)^{2}+\left(y_{2}-y\right)^{2}+\left(z_{2}-z\right)^{2}, \\
\left(D_{3}+D^{\prime}\right)^{2}=\left(x_{3}-x\right)^{2}+\left(y_{3}-y\right)^{2}+\left(z_{3}-z\right)^{2}, \\
\left(D_{4}+D^{\prime}\right)^{2}=\left(x_{4}-x\right)^{2}+\left(y_{4}-y\right)^{2}+\left(z_{4}-z\right)^{2}
\end{array} .\right.\right.
$$


Expand the brackets,

$$
\left\{\begin{array}{l}
D_{1}^{2}+2 D_{1} D^{\prime}+D^{\prime 2}=x_{1}^{2}-2 x_{1} x+x^{2}+y_{1}^{2}-2 y_{1} y+y^{2}+z_{1}^{2}-2 z_{1} z+z^{2} \\
D_{2}^{2}+2 D_{2} D^{\prime}+D^{\prime 2}=x_{2}^{2}-2 x_{2} x+x^{2}+y_{2}^{2}-2 y_{2} y+y^{2}+z_{2}^{2}-2 z_{2} z+z^{2} \\
D_{3}^{2}+2 D_{3} D^{\prime}+D^{\prime 2}=x_{3}^{2}-2 x_{3} x+x^{2}+y_{3}{ }^{2}-2 y_{3} y+y^{2}+z_{3}^{2}-2 z_{3} z+z^{2} \\
D_{4}^{2}+2 D_{4} D^{\prime}+D^{\prime 2}=x_{4}{ }^{2}-2 x_{4} x+x^{2}+y_{4}{ }^{2}-2 y_{4} y+y^{2}+z_{4}{ }^{2}-2 z_{4} z+z^{2}
\end{array}\right.
$$

From the first equation of the system, we subtract the second, third and fourth, and the third from the second equation.

$$
\begin{aligned}
& \left\{\begin{array}{l}
D_{1}^{2}-D_{2}^{2}+2 D_{1} D^{\prime}-2 D_{2} D^{\prime}=x_{1}^{2}-x_{2}^{2}-2 x_{1} x+2 x_{2} x+y_{1}^{2}-y_{2}^{2}-2 y_{1} y+2 y_{2} y+z_{1}^{2}-z_{2}^{2}-2 z_{1} z+2 z_{2} z, \\
D_{1}^{2}-D_{3}^{2}+2 D_{1} D^{\prime}-2 D_{3} D^{\prime}=x_{1}^{2}-x_{3}^{2}-2 x_{1} x+2 x_{3} x+y_{1}^{2}-y_{3}^{2}-2 y_{1} y+2 y_{3} y+z_{1}^{2}-z_{3}^{2}-2 z_{1} z+2 z_{3} z, \\
D_{1}^{2}-D_{4}^{2}+2 D_{1} D^{\prime}-2 D_{4} D^{\prime}=x_{1}^{2}-x_{4}^{2}-2 x_{1} x+2 x_{4} x+y_{1}^{2}-y_{4}^{2}-2 y_{1} y+2 y_{4} y+z_{1}^{2}-z_{4}^{2}-2 z_{1} z+2 z_{4} z, \\
D_{2}^{2}-D_{3}^{2}+2 D_{2} D^{\prime}-2 D_{3} D^{\prime}=x_{2}^{2}-x_{3}^{2}-2 x_{2} x+2 x_{3} x+y_{2}^{2}-y_{3}^{2}-2 y_{2} y+2 y_{3} y+z_{2}^{2}-z_{3}^{2}-2 z_{2} z+2 z_{3} z .
\end{array}\right. \\
& \left(2 x_{1} x-2 x_{2} x+2 y_{1} y-2 y_{2} y+2 z_{1} z-2 z_{2} z+2 D_{1} D^{\prime}-2 D_{2} D^{\prime}=x_{1}^{2}-x_{2}^{2}+y_{1}^{2}-y_{2}^{2}+z_{1}^{2}-z_{2}^{2}+D_{2}^{2}-D_{1}^{2}\right. \text {, } \\
& \left\{2 x_{1} x-2 x_{3} x+2 y_{1} y-2 y_{3} y+2 z_{1} z-2 z_{3} z+2 D_{1} D^{\prime}-2 D_{3} D^{\prime}=x_{1}^{2}-x_{3}^{2}+y_{1}^{2}-y_{3}^{2}+z_{1}^{2}-z_{3}^{2}+D_{3}^{2}-D_{1}^{2}\right. \text {, } \\
& 2 x_{1} x-2 x_{4} x+2 y_{1} y-2 y_{4} y+2 z_{1} z-2 z_{4} z+2 D_{1} D^{\prime}-2 D_{4} D^{\prime}=x_{1}^{2}-x_{4}{ }^{2}+y_{1}^{2}-y_{4}{ }^{2}+z_{1}^{2}-z_{4}^{2}+D_{4}^{2}-D_{1}^{2} \text {, } \\
& 2 x_{2} x-2 x_{3} x+2 y_{2} y-2 y_{3} y+2 z_{2} z-2 z_{3} z+2 D_{2} D^{\prime}-2 D_{3} D^{\prime}=x_{2}^{2}-x_{3}^{2}+y_{2}^{2}-y_{3}^{2}+z_{2}^{2}-z_{3}^{2}+D_{3}^{2}-D_{2}^{2} \text {. } \\
& \int\left(2 x_{1}-2 x_{2}\right) x+\left(2 y_{1}-2 y_{2}\right) y+\left(2 z_{1}-2 z_{2}\right) z+\left(2 D_{1}-2 D_{2}\right) D^{\prime}=x_{1}{ }^{2}-x_{2}{ }^{2}+y_{1}{ }^{2}-y_{2}{ }^{2}+z_{1}{ }^{2}-z_{2}{ }^{2}+D_{2}{ }^{2}-D_{1}{ }^{2} \text {, } \\
& \left\{\left(2 x_{1}-2 x_{3}\right) x+\left(2 y_{1}-2 y_{3}\right) y+\left(2 z_{1}-2 z_{3}\right) z+\left(2 D_{1}-2 D_{3}\right) D^{\prime}=x_{1}^{2}-x_{3}^{2}+y_{1}^{2}-y_{3}^{2}+z_{1}^{2}-z_{3}^{2}+D_{3}^{2}-D_{1}^{2}\right. \text {, } \\
& \left\{\left(2 x_{1}-2 x_{4}\right) x+\left(2 y_{1}-2 y_{4}\right) y+\left(2 z_{1}-2 z_{4}\right) z+\left(2 D_{1}-2 D_{4}\right) D^{\prime}=x_{1}{ }^{2}-x_{4}{ }^{2}+y_{1}{ }^{2}-y_{4}{ }^{2}+z_{1}{ }^{2}-z_{4}{ }^{2}+D_{4}{ }^{2}-D_{1}{ }^{2}\right. \text {, } \\
& \left(\left(2 x_{2}-2 x_{3}\right) x+\left(2 y_{2}-2 y_{3}\right) y+\left(2 z_{2}-2 z_{3}\right) z+\left(2 D_{2}-2 D_{3}\right) D^{\prime}=x_{2}{ }^{2}-x_{3}{ }^{2}+y_{2}{ }^{2}-y_{3}{ }^{2}+z_{2}^{2}-z_{3}^{2}+D_{3}^{2}-D_{2}^{2}\right. \text {. }
\end{aligned}
$$

Calculate them separately:

$$
\begin{aligned}
& \alpha_{1}=2 x_{1}-2 x_{2}, \alpha_{2}=2 x_{1}-2 x_{3}, \alpha_{3}=2 x_{1}-2 x_{4}, \alpha_{4}=2 x_{2}-2 x_{3}, \\
& \beta_{1}=2 y_{1}-2 y_{2}, \beta_{2}=2 y_{1}-2 y_{3}, \beta_{3}=2 y_{1}-2 y_{4}, \beta_{4}=2 y_{2}-2 y_{3} \text {, } \\
& \gamma_{1}=2 z_{1}-2 z_{2}, \gamma_{2}=2 z_{1}-2 z_{3}, \gamma_{3}=2 z_{1}-2 z_{4}, \gamma_{4}=2 z_{2}-2 z_{3} \text {, } \\
& d_{1}=2 D_{1}-2 D_{2}, d_{2}=2 D_{1}-2 D_{3}, d_{3}=2 D_{1}-2 D_{4}, d_{4}=2 D_{2}-2 D_{3}, \\
& b_{1}=x_{1}^{2}-x_{2}^{2}+y_{1}^{2}-y_{2}^{2}+z_{1}^{2}-z_{2}^{2}+D_{2}^{2}-D_{1}^{2}, \quad\left(\alpha_{1} x+\beta_{1} y+\gamma_{1} z+d_{1} D^{\prime}=b_{1}\right. \text {, }
\end{aligned}
$$

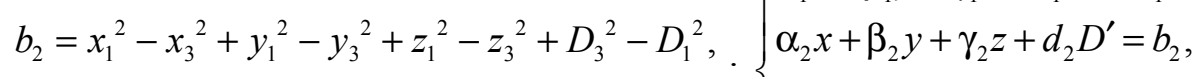

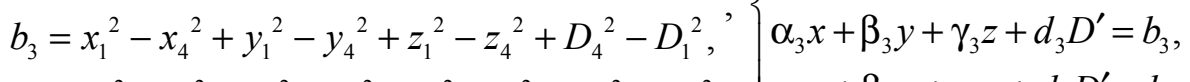

$$
\begin{aligned}
& b_{4}=x_{2}{ }^{2}-x_{3}{ }^{2}+y_{2}{ }^{2}-y_{3}{ }^{2}+z_{2}{ }^{2}-z_{3}{ }^{2}+D_{3}{ }^{2}-D_{2}{ }^{2} \quad \alpha_{4} x+\beta_{4} y+\gamma_{4} z+d_{4} D^{\prime}=b_{4}
\end{aligned}
$$

Find the solution to the system using the Cramer method [9] (2):

$$
\Delta=\left|\begin{array}{llll}
\alpha_{1} & \beta_{1} & \gamma_{1} & d_{1} \\
\alpha_{2} & \beta_{2} & \gamma_{2} & d_{2} \\
\alpha_{3} & \beta_{3} & \gamma_{3} & d_{3} \\
\alpha_{4} & \beta_{4} & \gamma_{4} & d_{4}
\end{array}\right|=\alpha_{1}\left|\begin{array}{lll}
\beta_{2} & \gamma_{2} & d_{2} \\
\beta_{3} & \gamma_{3} & d_{3} \\
\beta_{4} & \gamma_{4} & d_{4}
\end{array}\right|-\beta_{1}\left|\begin{array}{ccc}
\alpha_{2} & \gamma_{2} & d_{2} \\
\alpha_{3} & \gamma_{3} & d_{3} \\
\alpha_{4} & \gamma_{4} & d_{4}
\end{array}\right|+\gamma_{1}\left|\begin{array}{lll}
\alpha_{2} & \beta_{2} & d_{2} \\
\alpha_{3} & \beta_{3} & d_{3} \\
\alpha_{4} & \beta_{4} & d_{4}
\end{array}\right|-d_{1}\left|\begin{array}{lll}
\alpha_{2} & \beta_{2} & \gamma_{2} \\
\alpha_{3} & \beta_{3} & \gamma_{3} \\
\alpha_{4} & \beta_{4} & \gamma_{4}
\end{array}\right| .
$$

Then the solution has the form: $x=\frac{\Delta_{1}}{\Delta}, y=\frac{\Delta_{2}}{\Delta}, z=\frac{\Delta_{3}}{\Delta}, D^{\prime}=\frac{\Delta_{4}}{\Delta}$. Thus, the server receives distance data via Wi-Fi, and the coordinates of all installed BLE-beacons are also written on it, which allows us to accumulate in own database the coordinates of the location of the object in real time (Fig. 2). 


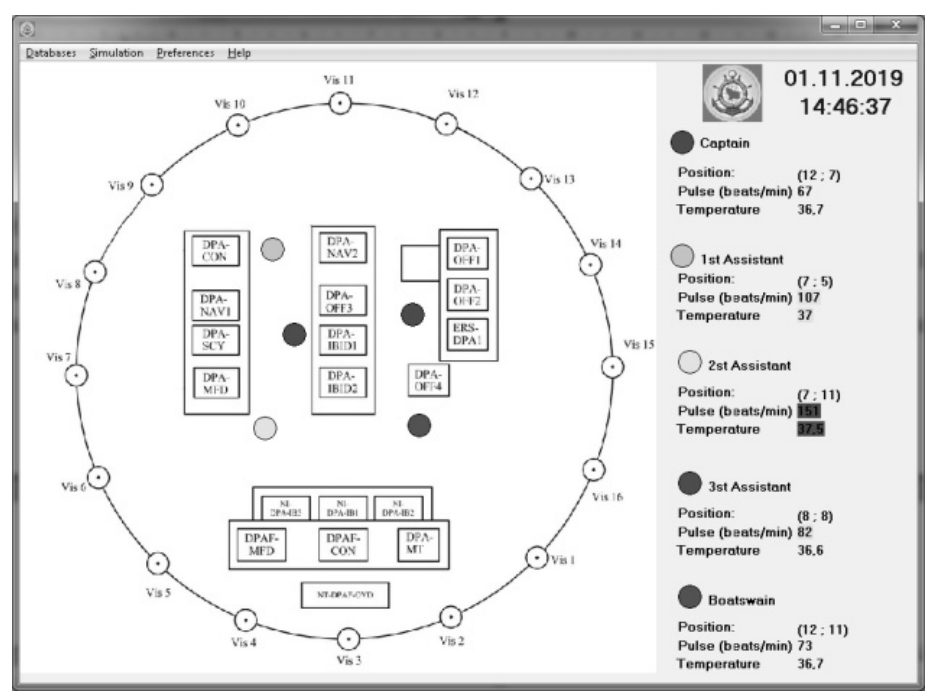

Figure 2. Definitions of the navigators position

$M_{i}$ beacons can be located at different heights, as well as $D_{k}$ body sensors. Taken this fact, there will be an intersection of three spheres. The common part of the intersection will also determine the location of the object with a specific sensor. The experiment showed that to identify the location of the navigators with the necessary accuracy, it is enough to place three sensors.

A special program is installed on the server, which registers the movements of all team members with connected sensors. All coordinates every $0.1 \mathrm{~s}$. are stored in the server database.

It is also possible to view all the movements of team members for the purpose of conducting a behavioral analysis. An additional analyzer is a portable earphone with a built-in supersensitive accelerometer, which allows us high accurately determine the turns of the head of the navigator. This is especially important in cases where the navigator, without changing of own location, analyze the situation.

Thus, the hardware-software complex at the first stage allows identify the location of the navigator and the position of the head in the form of a spatial vector (Fig. 3). However, it should be noted that the position of the head of the navigator does not give full confidence that he are watching directly, so further researches are aimed at determining the position of the pupils relative to the eye. Thus, it becomes possible to determine the vector direction of the view of the navigator in the conditions of the navigation watch.
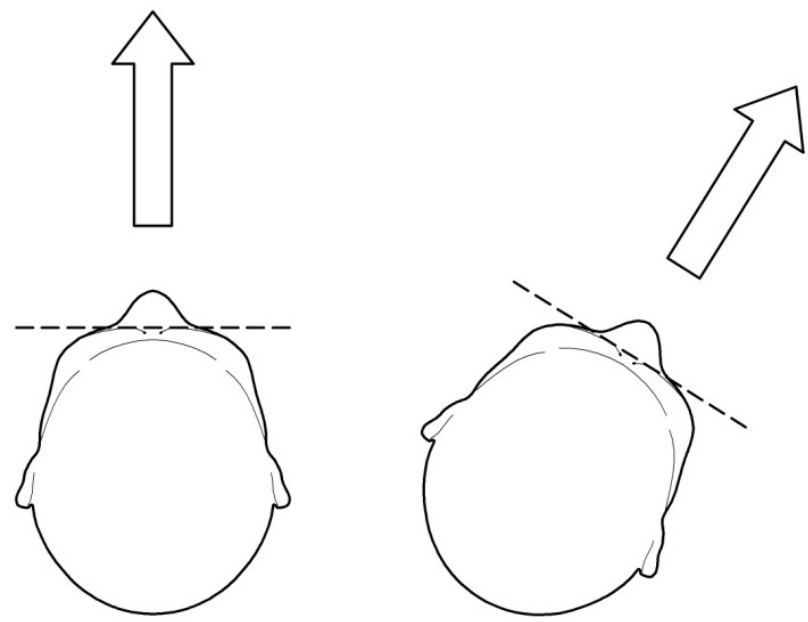

Figure 3. Direction determination of the view by the coordinates of the pupils in expanse

For this purpose, it is advisable to apply two methods sequentially - AdaBoost and Daugman, since the first is applicable for analyzing the movement and tracking of objects, i.e. it is used in cases of fast work, and the second for further clarification with detailed localization of the center of the pupil according to the formulas (3): 


$$
X=\arg \max _{x}\left(\sum_{y} \frac{\min }{x y}(I(x, y))\right), Y=\arg \max _{y}\left(\sum_{x} \frac{\min }{x y}(I(x, y))\right) .
$$

The clarification of the sign of the pupil in a given sector is carried out according to the formula:

$$
\max _{r, x_{0}, y_{0}}\left|\frac{\partial}{\partial r} \mathrm{G}_{\sigma}(r) * \oint \frac{I(x, y)}{2 \pi r} d s\right|
$$

where $\mathrm{G}_{\sigma}(r)$ - Gaus function with parameters $\sigma ;\left(x_{0}, y_{0}\right)$ - probable coordinates of the pupil; $r \in\left(r_{\min }, r_{\max }\right)$ - the radiuses of the borders of the iris.

The rotation of the head at an angle $a$ and $b$ is identified from the principle of identifying the coordinates of each eye $L\left(x_{A}, y_{A}, z_{A}\right), R\left(x_{B}, y_{B}, z_{B}\right)[10,11]$.

Thus, the navigator view direction vector is determined. To determine the exact direction, we need to consider a couple of images such that $\left\langle G_{L}, G_{R}\right\rangle=M_{3 D}\left(S_{o, b, j, n}, P_{S_{1 \ldots n}}\right)$. Linear horizontal $d_{1}, d_{2}$ and vertical $h_{1}, h_{2}$ displacements allow us to determine the point of concentration of the eye, taking into account the focal length: $f_{1}, f_{2}: x_{P}=\left(\frac{d_{2} \sin \alpha-f_{2} \cos \alpha}{d_{2} \cos \alpha-f_{2} \sin \alpha}\left(f_{2} \sin \alpha-x_{A}\right)+y_{A}-f_{2} \cos \alpha+f_{1}\right) / \frac{f_{1}}{d_{1}}-\frac{d_{2} \sin \alpha-f_{2} \cos \alpha}{d_{2} \cos \alpha-f_{2} \sin \alpha}$.

Then, $y_{P}=\frac{f_{1}}{d_{1}} x_{P}-f_{1}, z_{P}=\frac{h_{1}\left(y_{P}+f_{1}\right)}{f_{1}}$ with $G_{L(R)}=(x p, y p, z p)$.

In order to more accurately identification of eye coordinates, surveillance cameras are used to identify the position of the pupils in expanse based on the infrared radiation spectrum (Fig. $4 a, b$ ). Taken into account the delay in view on the equipment and visual observation when analyzing the navigation situation on average 2-7 seconds, we can conclude that this is quite enough to trigger the pupil coordinate identification system and determine the direction of the view.

According to the methodology presented in, the order can be represented in the form of an algorithm containing three main elements [12]: $A_{i}^{l-d}, l=1, \ldots, 3$ - identifier of one of the three types of SIS, $d$ - type of navigation device or overview ( $s$ - straight, $r$ - right, $l$ - left); $P_{i}$ - identifier for triggering concentration of attention on the $i$-th SIS, such that $p_{i}=\{0 ; 1\} ; \Omega_{i}$ - end of order. The abstract concept of an element in order is denoted by $O_{i}$.

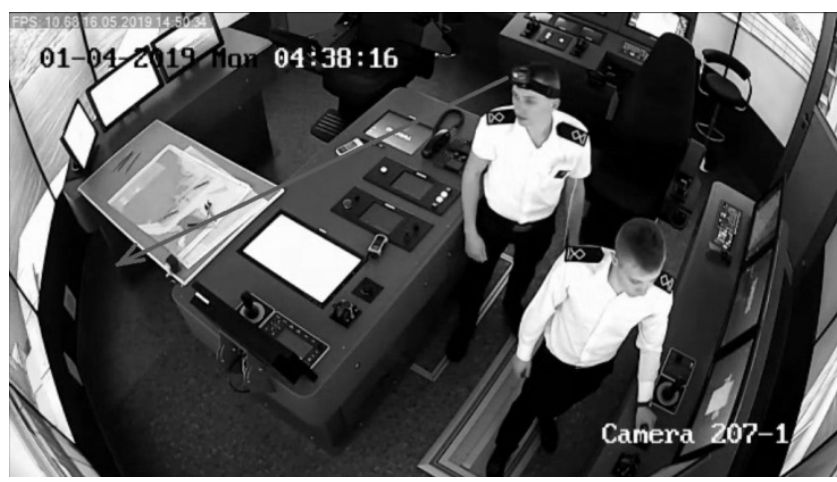

$a$

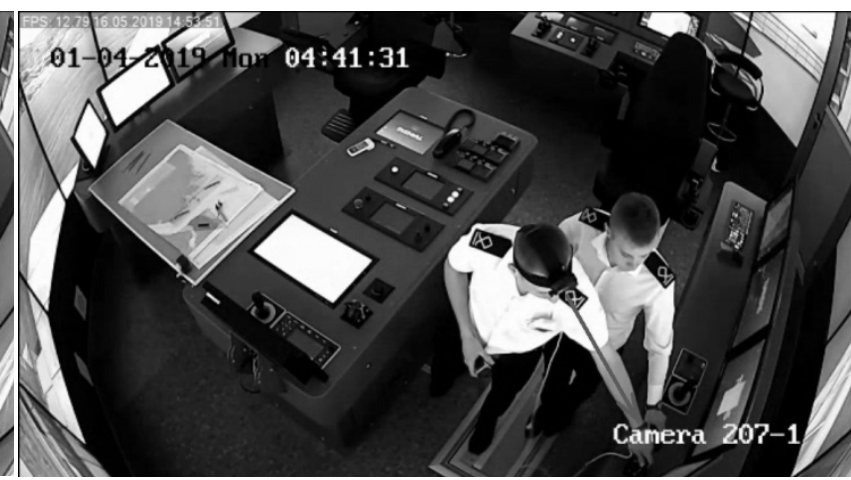

$b$

Figure 4. Spatial identification of the navigator view direction

The transition to a new element, depending on the most pronounced models of navigator behavior, is denoted by: $\stackrel{r}{\longrightarrow}$ with $p_{i}=1$ and $\longrightarrow$ if $p_{i}=0$. The dependence on the effectiveness of the triggering attention concentration is obvious; a positive result allows us to develop order in a direction different from negative and vice versa.

For example, a positive identification of signals from the radar allows synchronizing it with automatic identification system (AIS) parameters, which will more accurately determine the navigation situation. At the 
same time, a negative result will push the navigator to visual observation, which in conditions of restricted visibility can be a fatal error.

Imagine a situation when the navigator determines the following order (4):

$$
A_{1}^{2-s} P_{2} \stackrel{7}{\longrightarrow} A_{3}^{2-r} P_{4} \underset{5}{\longrightarrow} A_{5}^{2-l} P_{6} \stackrel{1}{\longrightarrow} A_{7}^{1-1} P_{8} \stackrel{11}{\longrightarrow} A_{9}^{1-3} P_{10} \stackrel{7}{\longrightarrow} A_{11}^{1-2} \Omega_{12} .
$$

So initially the navigator's actions are determined by visual observation dead a head $-A_{1}^{2-s}$; further, in the case of positive identification $P_{2} \stackrel{7}{\longrightarrow}$, the transition to the seventh element is carried out and characterized by the analysis of the navigation equipment (radar) $A_{7}^{1-1}$; if the result $P_{2}$ is negative, then two additional elements are involved: $A_{3}^{2-r}$ - observation to the right and $A_{5}^{2-l}-$ observation to the left; similarly, if $A_{7}^{1-1}$ the result $P_{8}$ is negative, then the navigator additionally turns to $A_{9}^{1-3}$ global positioning system (GPS) and only if positive result will immediately goes to $A_{11}^{1-2}$ Electronic Chart Display and Information System (ECDIS). Analyzing this order, we can conclude that the result in each element can be influenced by various factors and models of behavior, in particular, uncertainty in actions and restricted visibility will form a sequence $A_{1}^{2-s} A_{3}^{2-r} A_{5}^{2-l} P_{6}$, while an insufficient level of experience can cause a sequence $A_{7}^{1-1} A_{9}^{1-3} A_{11}^{1-2}$.

Thus, than the greater order in the numbers of SIS elements, then greater numbers of transitions are initiated; in some cases, closed $\mathrm{Si}$ cycles can lead to a loss of time for maneuvering and, as a consequence, to $\Omega_{i-\Delta_{t}}$, due to an accident. At the same time, too sharp a shift in attention to SIS elements creates gaps in the orders forming new, reduced in the numbers of elements and, as a result, less safe.

The approaches and principles outlined above require a more visual approximation in the form of geometric structures to classify models for analyzing the navigation situation during complicated maneuvers (Fig. 5). With this aim, software was developed that allowed the construction of models for the analysis of the navigation situation in the form of geometric structures. This software allows real-time construction and automatically predicts further events based on regression analysis of the navigator's information model data and fragments of the primary geometric structures of the navigation situation analysis model.

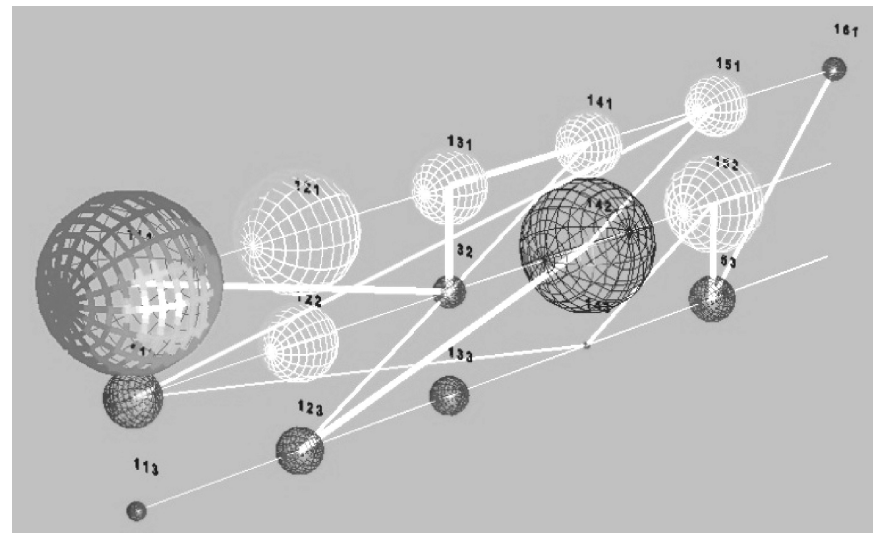

Figure 5. Geometric visualization of determining the areas of attention the navigator

The geometric structure is three vectors in the form of groups of information sources. Each vector will have a dimension by the number of information sources. The delay in view at the node - the source of information will form a sphere depending on the time in seconds. The speed of the transition from node to node will form a connection in the form of an edge of a geometric structure, while the thickness of the connection depends on the transition time, than longer the transition, then thicker the connection.

\section{Experement}

At the Kherson State Maritime Academy (KSMA), a scientific experiment was conducted at the TRANSAS [13], Virtual Ship Navigation Bridge Simulator Lab on the passage of the Hong Kong Port Navigation Area from Lamma Patch place to Ma Wan Bridge.

During the experiment, there were seven emergency situations that resulted to increased palpitation of the cadet (measurements were performed by a CARDIOLINE VSIGN10 instrument) acting on the bridge simulator of the virtual vessel as decision-making person (DMP). During emergencies, wrong or delayed 
actions by DMP twice resulted in a collision of own vessel with the target vessels and once resulted to grounding of the own virtual vessel at the midpoint and at the end of the experiment accordingly.

It should be noted that the absence of a stressful situation is also possible if there is a lack of experience of DMP and thus the inability to correctly and timely assess the development of a possible emergency situation, which leads to a relaxed behavior on the navigation bridge and delayed response to prevent negative consequences of emergencies. An example of such behavior is the stressful situation № 7, which resulted to the own vessel grounding in the shallows. During the course alteration of more than 90 degrees the DMP did not take into account the correct calculations of current, wind and sea waves affecting on the virtual vessel, as the result the incorrect calculation of the turning maneuver and late noting the negative development of the situation, which lead to impossibility correct the emergency situation and finally grounding of the virtual vessel. Straight prior to the moment of the grounding at the shallow the DMP remained calm and had no signs of a rapid heartbeat, which best indicates the stressful state and perception/understanding of the emergency situation.

Emergency maneuvering (stressful situation). In a stressful situation, the navigator's behavior model is as follows: a more experienced navigator continues to use the visual observation for the assessment of the situation, correcting it (if necessary) with the navigation equipments data, while the less experienced navigator will primarily focus on navigational equipment indicators almost ignoring the visual observation component, or randomly dispersing own attention between equipment indicators and visual observation without specifically focusing on the emergency situation solving.

All of these behaviors have the following disadvantages.

1. A visual observation and assessment of the situation is primarily based on the overall navigational experience of the navigator and, in the absence of sufficient experience, may lead to an overestimation of the own forces and skills and as a result of an underestimation of the current situation that may develop into an emergency.

2. Using only navigation equipment without a visual observation assessment of the situation leads to the loss of a correct understanding of the current navigation component, and in the conditions of excessive approximation of vessels (especially large tonnage) can follow to underestimate the itself situation of the approximation of two marine floating objects, as any marine radar or automatic radar plotting aid (ARPA) have their own error and so-called «dead zones» of use. Because the calculated data of ARPA or radar image can reassure the navigator of the safe passage of another object or target vessel, but the actual navigation situation will result in a collision or effect of the vessel interaction on the water. For example - stressful situation № 5 .

3. The chaotic dispersing of the DMP attention between the indicators of the navigation equipments and the visual observation assessment of the navigation situation makes it impossible to concentrate on the current problems solving and does not allow to formalize the information received, as well as indicates insufficient experience of the navigator and/or insufficient knowledge's to make a decision in a stressful situation. Seven of the following emergencies occurred during the experiment (Table)

$\mathrm{T}$ a b le

\section{Timeline of the experiment}

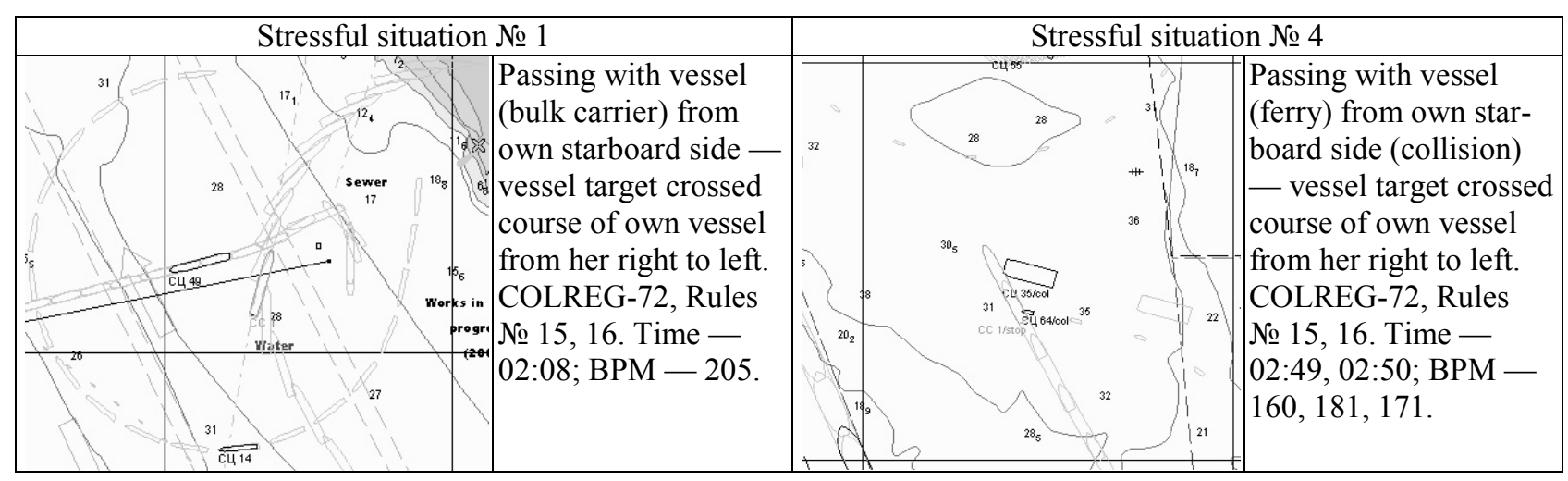




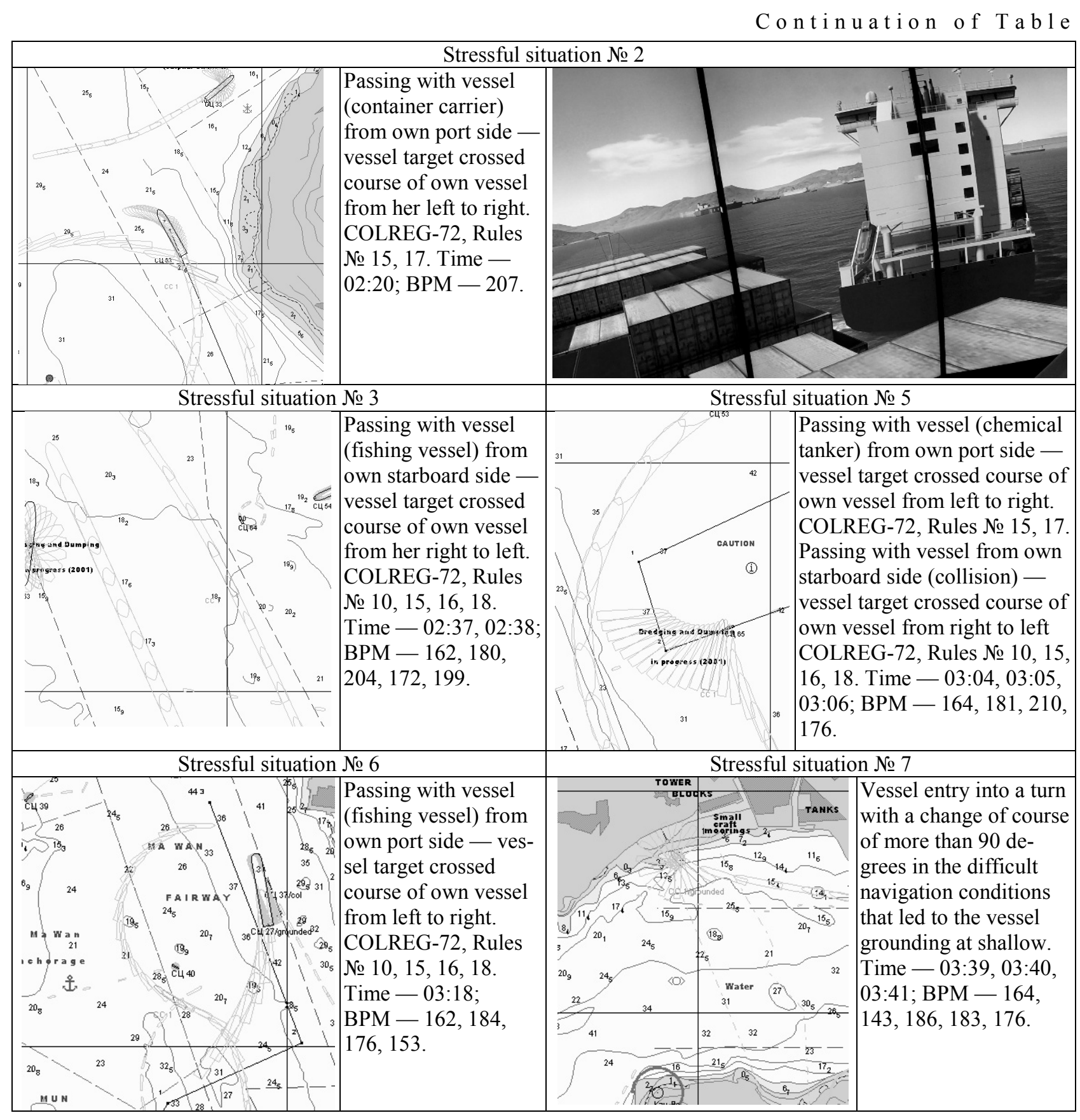

Note: BPM — beats per minute (heart rate palpitation).

\section{Conclusion}

This method allowed determining the number and sequence of cycles in order. This made it possible to detect individual models of navigators while identifying navigation situations. It is important to note that than more often cycles are repeated in orders, then stronger the connection with the elements of SIS. This fact has both a positive effect in the case of successful navigator actions and a negative one. The difficulty lies in the fact that, if necessary, adjusting the model of the navigator's behavior in conditions of strong connection, it is necessary to repeatedly work out new orders using navigation simulators.

Performed series of experiments using the Navi Trainer 5000 navigation simulator allowed us to identify dangerous cycles that do not lead to the final result, but are closed repeatedly, excluding important elements of the SIS due to lack of time.

Due to the fact that orders can include a sequence of several tens of SIS elements, the instructor must enter the required elements of the SIS before the experiment to determine dangerous cycles. After analyzing the data of 23 passages trajectories in Hong Kong locations, the most stable behavior models typical for 
these hydrographic features were identified. The hardware and software means developed for the experiments allowed us to determine the most and least applicable elements of the SIS, the likelihood of looping in complicated areas and, as a result, prevent the occurrence of emergency situations [14] in similar cartographic areas.

\title{
References
}

1 COLREGS - International Regulations for Preventing Collisions at Sea [Electronic resource] / Lloyd's Register Rulefinder 2005 - Version 9.4. — 2009. — Retrieved from: http://www.jag.navy.mil/distrib/instructions/ COLREG-1972.pdf

2 Nosov P.S. Identification of «Human error» negative manifestation in maritime transport / P.S. Nosov, A.P. Ben, V.N. Matejchuk, M.S. Safonov // Radio Electronics, Computer Science, Control. Zaporizhzhia National Technical University. 2018. — № 4(47). — P. 204-213. DOI: 10.15588/1607-3274-2018-4-20.

3 Emre A. A hybrid accident analysis method to assess potential navigational contingenciees: The case of ship grounding / A. Emre // Safety Science. — 2015. — Vol. 79. - P. 268-276. DOI: 10.1016/j.ssci.2015.06.019

4 Nosov P.S. Modeling the manifestation of the human factor of the maritime crew / P.S. Nosov, I.V. Palamarchuk, M.S. Safonov, V.I. Novikov // Dnipropetrovsk National University of Railway Transport named after Academician V. Lazaryan (Dnipro). — 2018. - No. 5 (77). — P. 82-92. DOI: 10.15802/stp2018/147937

5 Бауман Е.В. Методы размытой классификации (вариационный подход) / Е.В. Бауман // Автоматика и телемеханика. - 1988. - № 12. - C. 143-156.

6 Popovych I.S. The Structure, Variables and Interdependence of the Factors of Mental States of Expectations in Students' Academic and Professional Activities / I.S. Popovych, O.Ye. Blynova // The New Educational Review. — 2019. — No. 55(1). P. 293-306. DOI: 10.15804/tner.2019.55.1.24.

7 Nosov P. Approaches going to determination periods of the human factor of navigators during supernumerary situations / P. Nosov, A. Ben, A. Safonova, I. Palamarchuk // Radio Electronics, Computer Science, Control. — 2019. - No. 2(49). - P. 140150. DOI: $10.15588 / 1607-3274-2019-2-15$.

8 Застела М.Ю. Радиотехнические системы: учеб. пос. / М.Ю. Застела. - М.: Юрайт, 2018. — 495 с.

9 Ben-Israel A. Cramer rule for least-norm solution of consistent linear equations / A. Ben-Israel // Linear Algebra Applications. - 1982. - Vol. 43. - P. 223-226.

10 Болецкий Е.Б. Оптико-электронное устройство для бесконтактного управления автоматизированными подсистемами автомобиля: автореф. дис. ... канд. техн. наук: 05.13.05 - «Элементы и устройства вычислительной техники и систем управления» / Е.Б. Болецкий. — Курск, 2016. — 19 с.

11 Бабич Ю.І. Інформаційна технологія підвищення відмовостійкості ергатичних систем критичного застосування: дис. ... канд. техн. наук: спец. 05.13.06 - Інформ. технології / Ю.І. Бабич; наук. кер. П.С. Носов. — Одесса, 2015. — 141 с.

12 Мартынюк В.В. Выделение цепей в схеме алгоритма / В.В. Мартынюк // Журн. вычислит. мат. и мат. физ. - 1961. - T. 1, № 1. - C. 151-162.

13 Zinchenko S.M. Use of navigation simulator for development and testing ship control systems / S.M. Zinchenko, P.S. Nosov, V.M. Mateichuk, P.P. Mamenko, O.O. Grosheva // The international scientific and practical conference dedicated to the memory of professors Yu.Yu. Fomin and V.S. Semenov. - 2019. - P. 350-355.

14 Zinchenko S.M. Automatic collision avoidance with many targets, including maneuvring ones / S.M. Zinchenko, P.S. Nosov, V.M. Mateichuk, P.P. Mamenko, O.O. Grosheva // The international scientific and practical conference dedicated to the memory of professors Yu.Yu. Fomin and V.S. Semenov. — 2019. - P. 343-349.

\author{
П.С. Носов, И.В. Паламарчук, С.М. Зинченко, \\ И.С. Попович, Я.А. Нагрибельный, Г.В. Носова
}

\section{Теңіз көлігінің эргатикалық жүйелерінде навигатордың назарына эксперименттік сәйкестендіру кұралдарын жасау}

\begin{abstract}
Мақалада тар және порт жанындағы зоналарға өту кезінде кемежүргізушісінің навигациялық жағдайды талдау модельдерін анықтау мәселелері қарастырылған, бұл әсіресе қиын жағдайларда маңызды. Зерттеу аясында әдеби көздерге талдау жасалған, бұл арнайы эксперименттік құралдарды жасау үшін осы аймақты сипаттауға мүмкіндік берген. Негізгі мақсат ретінде мақалада навигатордың эргатикалық жүйенің субъектісі ретінде назар аударатын бағыттарды анықтауға арналған бағдарламалық-техникалық құралдарды әзірлеудің ресми логикалық тәсілдері ұсынылған. Жағдайды бағалау кезінде навигатордың аналитикалық қызметінің бұйрықтарын қалыптастыру тетігі, математикалық модельдер және капитан көпіріндегі навигатордың жағдайын анықтау құралдары анықталған. Тапсырыстарды геометриялық жақындастыру ұсынылған, олардың метрикасы дағдарысты жағдайларды анықтау уақытын едәуір қысқартып, жағымсыз салдардың алдын алады. Navi Trainer 5000 сертификатталған навигациялық тренажерін қолдану арқылы жүргізілген тәжірибелер пайдаланылған тәсілдердің тиімділігі мен практикалық құндылығын растады, бұл экипажды қайта даярлауды айтарлықтай жақсартады.
\end{abstract}

Кілт сөздер: тәжірибелік құралдар, назар аударатын зоналарды сәйкестендіру, модельдер тәртібі, капитан мінбесіндегі навигатордың орналасуы, эргатикалық жүйелер, қиын жағдайлар. 


\title{
П.С. Носов, И.В. Паламарчук, С.М. Зинченко, И.С. Попович, Я.А. Нагрибельный, Г.В. Носова \\ Разработка средств для экспериментальной идентификации внимания навигатора в эргатических системах морского транспорта
}

\begin{abstract}
В статье рассмотрены вопросы идентификации моделей анализа навигационной обстановки судоводителем во время выполнения перехода в узкостях и припортовых зонах, что особенно значимо в критических ситуациях. В рамках исследования проведен анализ литературных источников, что позволило охарактеризовать данное направление как актуальное для разработки специальных средств экспериментального характера. В качестве основной цели в статье представлены формально-логические подходы разработки программно-аппаратных средств определения зон внимания навигатора как субъекта эргатической системы. Были определены механизм формирования порядков аналитической деятельности навигатора в ходе оценки ситуации, математические модели, средства для уточнения положения навигатора на капитанском мостике. Предложена геометрическая аппроксимация порядков, метрика которой позволяет значительно уменьшить время идентификации критических ситуаций и предотвратить негативные последствия. Проведенные эксперименты с использованием сертифицированного навигационного тренажера Navi Trainer 5000 подтвердили результативность и практическую ценность использованных подходов, что в значительной мере позволило улучшить переподготовку плавсостава.
\end{abstract}

Ключевые слова: экспериментальные средства, идентификация зон внимания, модели поведения, положение навигатора на капитанском мостике, эргатические системы, критические ситуации.

\section{References}

1 COLREGS - International Regulations for Preventing Collisions at Sea (2009). Lloyd's Register Rulefinder 2005, Version 9.4. Retrieved from: http://www.jag.navy.mil/distrib/instructions/COLREG-1972.pdf

2 Nosov, P.S., Ben, A.P., Matejchuk, V.N., \& Safonov, M.S. (2018). Identification of «Human error» negative manifestation in maritime transport. Radio Electronics, Computer Science, Control. Zaporizhzhia National Technical University, 4(47), 204-213, DOI: 10.15588/1607-3274-2018-4-20.

3 Emre, A. (2018). A hybrid accident analysis method to assess potential navigational contingenciees: The case of ship grounding. Safety Science, 79, 268-276, DOI: 10.1016/j.ssci.2015.06.019

4 Nosov, P.S., Palamarchuk, I.V., Safonov, M.S., \& Novikov, V.I. (2018). Modelling the manifestation of the human factor of the maritime crew. Dnipropetrovsk National University of Railway Transport named after Academician V. Lazaryan (Dnipro), 5 (77), 82-92, DOI: 10.15802/stp2018/147937

5 Bauman, E.B. (1988). Metody razmytoi klassifikatsii (variatsionnyi podkhod) [Fuzzy classification methods (variational approach)]. Avtomatika i telemekhanika - Automation and telemechanics, 12, 143-156 [in Russian].

6 Popovych, I.S. \& Blynova, O.Ye. (2019). The Structure, Variables and Interdependence of the Factors of Mental States of Expectations in Students' Academic and Professional Activities. The New Educational Review, 55(1), 293-306, DOI: 10.15804/tner.2019.55.1.24.

7 Nosov, P., Ben, A., Safonova, A., \& Palamarchuk, I. (2019). Approaches going to determination periods of the human factor of navigators during supernumerary situations. Radio Electronics, Computer Science, Control, 2(49), 140-150, DOI: 10.15588/1607-3274-2019-2-15.

8 Zastela, M. Yu. (2018). Radiotekhnicheskie sistemy [Radio Engineering Systems]. Moscow: Yurait Publishing House [in Russian].

9 Ben-Israel, A. (1982). Cramer rule for least-norm solution of consistent linear equations. Linear Algebra Applications, 43, $223-226$.

10 Boletsky, E.B. (2016). Optiko-elektronnoe ustroistvo dlia beskontaktnoho upravleniia avtomatizirovannymi podsistemami avtomobilia [Optoelectronic device for contactless control of automated car subsystems]. Candidate's thesis. Kursk [in Russian].

11 Babich, Yu.I. (2015). Informatsiina tehnolohiia pidvyshchennia vidmovostiikosti erhatychnykh system krytychnoho zastosuvannia [Information technology for increasing the resiliency of ergatic systems of critical use]. Candidate's thesis. Odessa.

12 Martynyuk, V.V. (1961). Vydelenie tsepei v skheme alhoritma [Selection of circuits in the algorithm scheme]. Zhurnal vychislitelnoi matematiki i matematicheskoi fiziki - Magazine of computational mathematics and mathematical physics, 1, 1, 151-162 [in Russian].

13 Zinchenko, S.M., Nosov, P.S., Mateichuk, V.M., Mamenko, P.P., \& Grosheva, O.O. (2019). Use of navigation simulator for development and testing ship control systems. The international scientific and practical conference dedicated to the memory of professors Yu.Yu. Fomin and V.S. Semenov, 350-355.

14 Zinchenko, S.M., Nosov, P.S., Mateichuk, V.M., Mamenko, P.P., \& Grosheva, O.O. (2019). Automatic collision avoidance with many targets, including maneuvring ones. The international scientific and practical conference dedicated to the memory of professors Yu.Yu. Fomin and V.S. Semenov, 343-349. 